\title{
Strategi Aktif dan Strategi Pasif Menggunakan Analisis Teknikal Saham Aali, Tlkm, Bbri dan Bbca pada Semester 1 Tahun 2020 di Bursa Efek Indonesia (BEI)
}

\author{
Oleh : Dr. Hartono \\ Universitas Widya Dhama Pontianak \\ Jl. HOS Cokroaminoto No. 445 Pontianak \\ Email : hartono@widyadharma.ac.id
}

\begin{abstract}
This study aims to see the measure between the average price of the MACD indicator with the closest average price of the shares of the company PT. Astra Agro Lestari Tbk, PT. Telkom, Bank BRI and Bank $B C A$. This type of research is descriptive with a quantitative approach and the sampling technique used is purposive sampling method. Based on predetermined criteria, 4 companies were obtained as samples with the code: AALI, TLKM, BBRI and BBCA. The research data analysis technique begins by recording the price of the MACD indicator using the ChartNexus Version 5 software and pairing it with the closest closing price of the stock, then testing it using the independent sample t test. The results show that there is no difference between the average price of the MACD indicator and the closest average price of shares, so that the buy and sell signals generated by the MACD indicator are accurate and can be used in stock trading. The results also found that there were market conditions (IHSG) during the study period, namely bearish conditions in the 1st semester of 2020.
\end{abstract}

Keywords: IHSG, Bearish, Technical Analysis, MACD, Bluechip Stock.

\section{PENDAHULUAN}

Di tengah maraknya pandemi Covid-19 membuat lesunya IHSG dan saham-saham yang ada di Bursa Efek Indonesia. Pandemi Covid19 juga menyebabkan banyaknya pemutusan hak kerja (PHK) oleh perusahaan, rumah makan, restoran, kafe, dan lain sebagainya yang terkena imbas Covid-19.

Perekonomian Indonesia semakin melemah dan menguatnya nilai tukar Rupiah di pasar saham Nasdaq. Hal tersebut disebabkan karena masyakat Indonesia yang menerapkan sistem lockdown dan PSBB, sehingga perekonomian masyarakat tidak bergairah.
Pada semester 1 tahun 2020, IHSG anjlok dan masyarakat berbondong-bondong beralih membeli emas sebagai investasi. Masyarakat percaya jika di saat pandemi seperti ini menyimpan emas dan uang tunai atau cash akan mengamankan ekonomi mereka.

Dua analisis yang dapat digunakan setiap investor dalam mengambil keputusan investasi adalah analisis fundamental dan analisis teknikal. Menurut Wira (2014:3-4), analisis fundamental memperhitungkan berbagai faktor, seperti kondisi ekonomi suatu negara, kebijakan ekonomi, baik makro ataupun mikro, sedangkan analisis teknikal adalah teknik yang menganalisa fluktuasi harga dalam rentang 
waktu tertentu atau dalam hubungannya dengan faktor lain misalnya volume transaksi. Karena itu, analisis teknikal banyak menggunakan grafik. Dari pergerakan tersebut akan terlihat pola tertentu yang dapat dipakai sebagai dasar untuk melakukan pembelian atau penjualan.

Bagi orang awam, analisis teknikal lebih mudah dipelajari daripada analisis fundamental karena hanya perlu bisa membaca grafik, sedangkan analisis fundamental membutuhkan setidaknya pengetahuan tentang ekonomi makro dan mikro (Wira, 2014:4). Analisis teknikal menggunakan indikator untuk membantu dalam proses analisis saham. Salah satu indikator yang mudah dan sering digunakan adalah indikator MACD yang diciptakan oleh Gerald Appel pada tahun 1970an. Menurut Wira (2014:107), Moving Average Convergence Divergence (MACD) adalah indikator yang sangat berguna bagi seorang trader. Indikator ini berfungsi untuk menunjukkan trend yang sedang terjadi. MACD dapat digunakan untuk mengetahui kondisi yang sedang terjadi dalam perdagangan saham.

Di pasar saham tahun 2020 ini, Indeks Harga Saham Gabungan telah mengalami penurunan yang dimulai sejak periode awal Februari. Di periode tersebut IHSG yang pada bulan sebelumnya masih di atas indeks 6.000 menunjukkan pelemahan dan terus bergerak melemah.

Bahkan pada minggu ketiga Maret mencapai level terendah di angka indeks 3.937. Selama dua bulan tersebut, akhir Januari sampai akhir Maret, IHSG tergerus di atas 2000 poin atau anjlok di atas 30\%. Pelemahan indeks saham tidak hanya di Indonesia, namun juga terjadi secara global.
Makin meluasnya penyebaran virus Covid 19 banyak disebut telah mendorong pelemahan indeks saham. Efek pelambatan ekonomi, proyeksi pelambatan pertumbuhan ekonomi, kebijakan yang ambigu dalam penanganan wabah telah berdampak sentimen negatif di pasar saham.

Hal tersebut telah berdampak bagi investor untuk mengevaluasi kembali portofolionya, terlebih di negara-negara berkembang termasuk Indonesia. Para investor menjadi terlalu berhati-hati dan faktor kondisi ekonomi dianggap tidak mendukung untuk pengambilan risiko. Bahkan obligasi pemerintah di Asia yang menawarkan imbalan tinggi juga tidak menarik lagi bagi investor.

Pada akhir Maret 2020, setelah mencapai titik terendah, IHSG berangsur-angsur menunjukkan pergerakan meningkat dengan fluktuasi minor. IHSG tercatat menguat sampai kisaran 4.800. Beberapa sentimen positif pendorong IHSG antara lain penguatan WTI Crude Oil hampir $16 \%$, juga menguatnya harga komoditas lain seperti batu bara, emas, dan CPO.

Penelitian ini berfokus pada perdagangan saham pada 6 bulan (semester 1) di tahun 2020 . Pada tahun tersebut IHSG mengalami bearish yang cukup tajam dikarenakan berbagai kondisi politik dan ekonomi di dalam negeri maupun luar negeri seperti kebijakan bank sentral Amerika dan kebijakan tax amnesty. IHSG mengalami kondisi bearish yang cukup parah sampai pada level 3937.

Objek pada penelitian ini adalah perusahaan dengan kode saham TLKM, BBRI, BBCA dan AALI. Tujuan penelitian ini adalah untuk mengetahui apakah terdapat perbedaan antara rata-rata harga dari indikator MACD dengan rata-rata close price terdekat saham perusahaan 
di BEI periode Januari 2020 hingga Juni 2020.

Penelitian tentang indikator MACD dalam perdagangan saham dilakukan oleh Asthri, Topowijono, \& Sulasmiyati (2016), yang menyatakan bahwa tidak terdapat perbedaan yang signifikan antara sinyal beli dan sinyal jual sebelum MACD dan sesudah MACD, sehingga analisis teknikal dengan indikator MACD akurat dan dapat dijadikan pedoman dalam penentuan sinyal membeli dan menjual dalam perdagangan saham pada sub sektor makanan dan minuman di BEI. Sedangkan penelitian Raditya, Tarno, \& Wuryandari (2013), menyimpulkan bahwa mean harga yang dihasilkan analisis MACD sama dan signifikan dengan mean harga penutupan sehingga dapat memberikan rata-rata keuntungan sebesar $5,97 \%$ hingga $14,29 \%$ atau diatas rata-rata tingkat inflasi aktual tahun 2012 yang bernilai $4,30 \%$.

\section{METODE PENELITIAN}

Jenis penelitian ini adalah deskriptif dengan pendekatan kuantitatif. Menurut Sujarweni (2015:49), penelitian deskriptif adalah penelitian yang dilakukan untuk mengetahui nilai masing-masing variabel, baik satu variabel atau lebih sifatnya independen tanpa membuat huubungan maupun perbandingan dengan variabel yang lain atau suatu penelitian yang dilakukan dengan tujuan utama untuk memberikan gambaran atau deskripsi tentang suatu keadaan secara objektif. Menurut Sugiyono (2014:7), metode ini disebut metode kuantitatif karena data penelitian berupa angkaangka dan analisis menggunakan statistik.

\section{OBJEK PENELITIAN}

Objek yang digunakan dalam penelitian ini adalah saham Bluechip yang terdaftar di Bursa Efek Indonesia (BEI) periode semester 1 tahun
2020, yaitu Januari 2020 sampai dengan Juni 2020. Data perusahaan terdaftar diperoleh dari alamat website www.idx.co.id.

\section{POPULASI DAN SAMPEL}

Populasi dalam penelitian ini adalah 4 perusahaan saham Bluchip yang terdaftar di Bursa Efek Indonesia periode Januari 2020 sampai Juni 2020. Pengambilan sampel dalam penelitian ini dilakukan dengan menggunakan teknik non-probability sampling, yaitu purposive sampling. Pada penelitian ini, terdapat 4 perusahaan yang terpilih sebagai sampel.

\section{DEFINISI OPERASIONAL VARIABEL}

\section{Harga dari Indikator MACD}

Harga dari indikator MACD didapat dari sinyal beli dan sinyal jual yang dihasilkan oleh indikator tersebut. Sinyal beli terjadi ketika garis MACD memotong garis sinyal ke atas (golden cross) dan sinyal jual terjadi ketika garis MACD memotong ke bawah garis sinyal (death cross).

\section{Close Price Terdekat Saham}

Close price terdekat adalah harga historis saham yang didapat dari close price terendah atau tertinggi saham harian sebelum atau sesudah terjadinya sinyal golden cross atau death cross.

\section{TEKNIK PENGUMPULAN DATA}

Teknik pengumpulan data yang digunakan pada penelitian ini adalah dokumentasi, yaitu mencari data dengan menggunakan berbagai referensi dari buku dan website yang berhubungan dengan materi penelitian ini. Selain itu, sumber data dalam penelitian ini juga didapat dengan cara mengunduh file dari situs internet seperti Bursa Efek Indonesia melalui www.idx.co.id. 


\section{TEKNIK ANALISIS DATA}

1. Pendataan sinyal beli dan sinyal jual menggunakan indikator MACD

2. Pendataan close price (terendah atau tertinggi) terdekat
3. Uji Normalitas data

4. Menguji rata-rata dua sampel independen menggunakan uji beda

5. Menarik kesimpulan dari hasil penggunaan indikator MACD terhadap 4 sampel perusahaan yang diteliti.

\section{HASIL DAN PEMBAHASAN}

Tabel 1. Jumlah Sinyal Indikator MACD

\begin{tabular}{ccccc}
\hline & \multicolumn{4}{c}{ KODE SAHAM } \\
\hline JAN-JUN 2020 & BBCA & TLKM & BBRI & AALI \\
\hline & 17 & 15 & 6 & 5 \\
\hline
\end{tabular}

Sumber: Data diolah,2020

Tabel 1 menunjukkan jumlah sinyal indikator MACD pada Januari 2020 sampai dengan Juni 2020, di mana pada tahun 2020 kondisi pasar sedang dalam tren bearish. Jumlah sinyal dari setiap saham berbeda yaitu, kode BBCA sebanyak 17 sinyal, BBRI sebanyak 6 sinyal, AALI sebanyak 5 sinyal dan TLKM sebanyak 15 sinyal.

Kondisi pasar (IHSG) yang sedang turun di Semester 1 tahun 2020 membuat para investor lebih sering keluar masuk pasar dalam jangka waktu yang tidak terlalu panjang. Dari 4 sampel penelitian, BBCA merupakan saham yang paling banyak memiliki sinyal dari indikator MACD

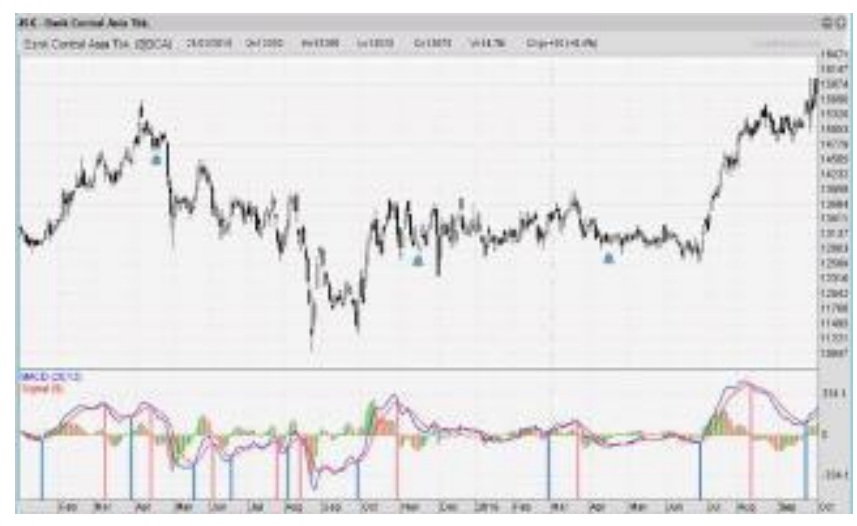

Gambar 1. Indikator MACD pada saham BBCA 


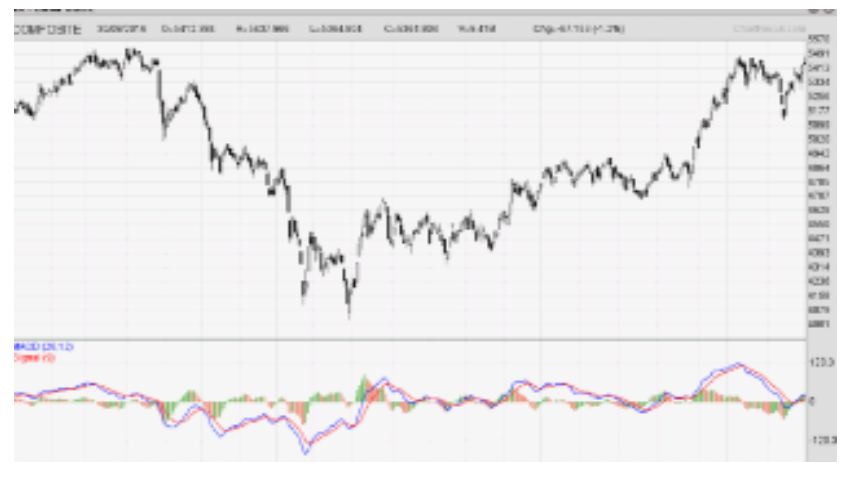

Gambar 2. Indikator pada saham TLKM

Perlakuan indikator MACD terhadap saham sampel penelitian saat kondisi pasar bearish dan bullish pada dasarnya tidak terlalu berbeda. Pada saat kondisi pasar bearish, investor perlu lebih berhati-hati saat membeli atau menjual saham menggunakan indikator MACD, sebab kondisi pasar sedang dalam tren menurun dengan psikologis pelaku pasar (investor) yang tidak bisa ditebak. Berbeda dengan kondisi bullish, pada saat pasar (IHSG) dalam tren naik, harga saham cenderung berfluktuatif wajar dengan tren harga yang meningkat, sehingga investor cukup untuk membeli saham yang sedang golden cross dan hold (tahan) sampai harga benar-benar tinggi untuk dijual.

Sesuai dengan tujuan awal penelitian, maka sinyal dari indikator MACD yang telah didata dipasangkan dengan close price terdekat sebagai perbandingan harga saham. Tabel pasangan harga telah dibuat dan dijelaskan pada bagian analisis deskriptif data. Data pasangan harga dari sinyal MACD dan close price terdekat 4 sampel kemudian diuji dengan uji normalitas Kolmogorov Smirnov dan uji Independent sample t-test.

Uji normalitas dilakukan menggunakan software SPSS 16.0 yang berguna untuk mengetahui apakah data berdistribusi normal atau tidak. Dari hasil pengujian, nilai Asymp. Sig. (2-tailed) adalah sebesar 0,089 atau berada diatas tingkat signifikansi $(0,05)$ yang berarti data berdistribusi secara normal. Setelah mengetahui data berdistribusi normal, uji selanjutnya yang dilakukan adalah uji beda. 
Tabel 2. Hasil Uji Independent Sample t-

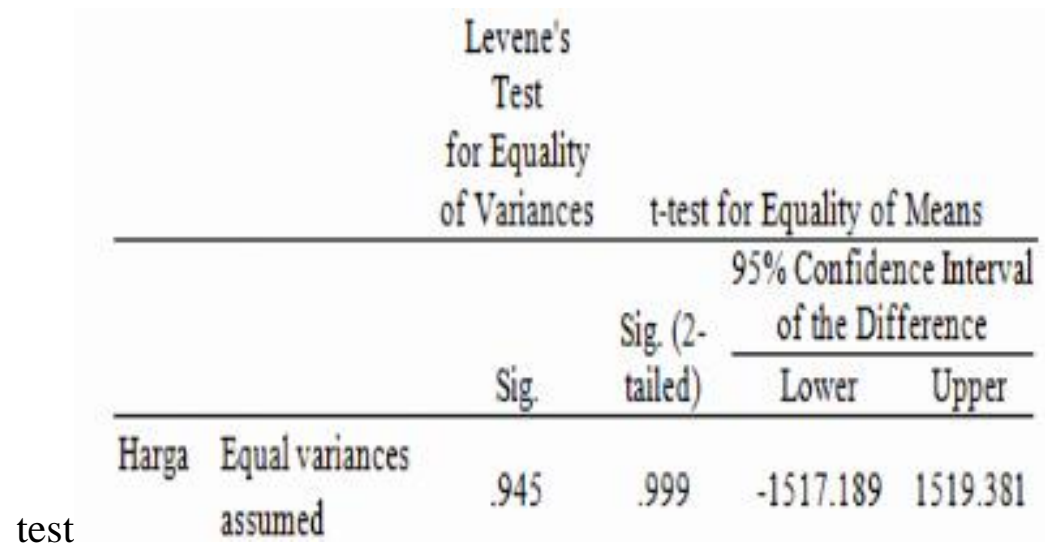

Hasil uji hipotesis independent sample t-test terhadap 5 sampel penelitian pada tabel 2 diatas menunjukkan nilai Asymp. Sig. (2-tailed) sebesar 0,999. Nilai tersebut berada diatas tingkat signifikansi 0,05 yang berarti menerima H0 dan menolak H1, sehingga dapat dikatakan bahwa tidak terdapat perbedaan antara rata- rata harga indikator MACD dengan rata-rata close price terdekat saham. Hasil ini menunjukkan bahwa sinyal beli dan sinyal jual yang dihasilkan oleh indikator MACD adalah akurat dan dapat digunakan dalam perdagangan saham.

\section{KESIMPULAN}

Kondisi pasar IHSG pada penelitian ini, yaitu kondisi bearish di semester 12020 .

Hasil uji hipotesis Independent sample ttest terhadap 4 sampel penelitian pada tabel 2 diatas menunjukkan nilai Asymp. Sig. (2-tailed) sebesar 0,999. Nilai tersebut berada diatas tingkat signifikansi 0,05 yang berarti menerima $\mathrm{H}_{0}$ dan menolak $\mathrm{H}_{1}$, sehingga dapat dikatakan bahwa tidak terdapat perbedaan antara rata- rata harga indikator MACD dengan rata-rata close price terdekat saham.

Hasil ini menunjukkan bahwa sinyal beli dan sinyal jual yang dihasilkan oleh indikator MACD adalah akurat dan dapat digunakan dalam perdagangan saham.

\section{SARAN}

Bagi para investor disarankan lebih berhatihati dalam melakukan perdagangan saat kondisi pasar sedang bearish karena pergerakan saham sangat fluktuatif dan lebih spekulatif dibanding perdagangan saham pada saat kondisi pasar bullish.

Bagi penelitian selanjutnya disarankan untuk menggunakan analisis fundamental perusahaan selain analisis harga secara teknikal, agar penentuan sinyal beli dan sinyal jual dalam perdagangan saham lebih akurat.

\section{DAFTAR PUSTAKA}

Asthri, Dian Dwi Parama Asthri., Topowijono, \& Sulasmiyati, Sri. (2016). Analisis Teknikal dengan Indikator Moving Average Convergence Divergence untuk Menentukan Sinyal Membeli dan Menjual dalam Perdagangan Saham. Jurnal Administrasi Bisnis (JAB), Vol. 33 No. 2 April 2016.

Bursa Efek Indonesia. (www.idx.co.id)

Raditya, Tri Murda Agus., Tarno, \& Wuryandari, Triastuti. (2013). Penentuan Tren 
Arah Pergerakan Harga Saham dengan Menggunakan Moving Average Convergence Divergence. Jurnal Gaussian, Vol.2, No.3, Th.2013, hlm 249- 258.

Sugiyono. (2014). Metode Penelitian

Kuantitatif Kualitatif dan R\&D. Bandung:
Sujarweni, Wiratna. (2015). Metodologi Penelitian Bisnis \& Ekonomi. Yogyakarta: Pustaka Baru Press.

Wira, Desmond. 2014. "Analisis Teknikal untuk Profit Maksimal”. (Edisi 2). 